\title{
Reconciliation and Peace Building in International Relations: An Empirical Analysis of Five Cases
}

\author{
Chengqiu Wu ${ }^{1,} \cdot$ Fan Yang ${ }^{1}$
}

Received: 6 June 2016/Accepted: 12 September 2016/Published online: 12 October 2016

(C) Fudan University and Springer Science+Business Media Singapore 2016

\begin{abstract}
To understand why some former adversaries have achieved deeper reconciliation than others, this article conducts an empirical study on five cases of reconciliation and peace building in the post-World War II era: the Franco-German relations, the Polish-German relations, the Polish-Soviet (Russian) relations, the South Korean-Japanese relations, and the Sino-Japanese relations. We distinguish between reconciliation and peace building and propose a series of factors including postwar political arrangements, regime change for perpetrator, alliance, regime type, and regional institutions to explain the variations among the cases in the degree of reconciliation and the degree of peace. It is argued that these factors have impacts on the degree of reconciliation, and that together with the latter, they also affect the degree of peace. It is also argued that there have been structural and historical reasons for the underdevelopment of reconciliation in Northeast Asia.
\end{abstract}

Keywords Reconciliation · Peace building · International relations

\section{Introduction}

In an international system characterized by anarchy, states face security threat from others, and peace among them is usually the result of balance of power, economic interdependence, or geographical distance and barriers. For two former antagonistic states to become friends and reach peace, they not only need to overcome security dilemma in general, but also to go through a process of reconciliation. In recent years, reconciliation has emerged as an important area of inquiry in international relations. Both empirical and theoretical studies on reconciliation have received

Chengqiu Wu

chqwu@fudan.edu.cn

1 School of International Relations and Public Affairs, Fudan University, Shanghai, China 
growing interest from scholars. On the empirical side, examples are Lind's (2008) comparative study of the effects of Japan's remembrance of its colonial past on its relations with South Korea and the effects of West Germany's remembrance of World War II on its relations with France, Ku's (2008) analysis of the different processes and outcomes of reconciliation between South Korean-Japanese relations and Franco-German relations, and He's (2009) study of Sino-Japanese relations and Polish-German relations to explain the path to deep interstate reconciliation. On the theoretical side, examples are Long and Brecke's (2003) study of the impacts of reconciliation on peace building after domestic and international conflicts, BarSiman-Tov's (2004) comprehensive theoretical exploration of reconciliation, and Tang's (2011) review of reconciliation as an area of academic inquiry and his exploration of the major conceptual, theoretical and methodological issues related to reconciliation. A research question of lasting interest is: why some former adversaries have achieved deeper reconciliation than others? While the abovementioned empirical works examine their particular cases with an emphasis on particular parts or factors of the reconciliation process (Lind on the effects of perpetrator countries' national debates triggered by their contrition in international reconciliation, $\mathrm{Ku}$ on the dynamics of political leaders and nongovernmental organizations on the outcome of reconciliation, and $\mathrm{He}$ on the competing significances of international structural conditions and national mythmaking), they have not examined multiple cases systematically by assessing the relationship between the values of a series of factors and the outcomes of reconciliation ${ }^{1}$. Tang (2011) uncovers the role of ethnocentrism and spiral in the institutionalization of conflict, and he lists a series of domestic and international factors that affect reconciliation including regime type, regime security, social cohesion, leaders' preference, distribution of power, coalitions, presence of regional organizations, regional identities, global norms, etc ${ }^{2}$. Yet in the review article, he does not empirically examine the effects of these factors on reconciliation, and his conceptual treatment of reconciliation by equating it to peace building deserves further discussion and critiques.

This article attempts to clarify the relationship between reconciliation and peace building and answer the research question "why some former adversaries have achieved deeper reconciliation than others" by examining five cases-the FrancoGerman Relations, the Polish-German relations, the Polish-Soviet (Russian) relations, the South Korean-Japanese relations, and the Sino-Japanese relations. More specifically, we distinguish between reconciliation and peace building, clarify different states of reconciliation, and examine the above-mentioned cases to propose a number of factors to explain the variation in degree of reconciliation and the variation in degree of peace. While the number of cases seems too large for a wieldy research, we believe it is necessary to include all the five cases for the following reasons. First, by including multiple cases, we can evaluate whether cases of small

\footnotetext{
1 Lind (2008, 9-10) does mention other factors including regime type, membership in international institutions, and territorial disputes as bases on which to judge states' intention, which in turn has an effect on the outcome of reconciliation.
}

2 P. 732. 
variations in their independent variables will have differences in their dependent variables (i.e., differences in degree of reconciliation and degree of peace). By comparing these cases, we can see the effects of multiple factors on reconciliation and peace building. Second, by including multiple cases, we have cases of variations in the degree of reconciliation and the degree of peace, so that we can avoid the selection bias problem-that is, selecting cases based on the value of dependent variable ${ }^{3}$. Third, all the five cases are well-known major cases of reconciliation and peace building in international relations, having received a large amount of scholarly attention, and thus we do not need much ink to describe their details.

The five cases that we select cover the geopolitical landscape across the Eurasia. The regional politics in Europe and that in Northeast Asia have formed contrasting pictures: while European countries have successfully overcome their historic animosity and constructed a security community, Northeast Asian countries are still trapped by the past, with very low level of trust among China, Japan, and South Korea and little progress in political regionalization beyond economic interdependence. People who believe Japan has not apologized enough tend to attribute Japan's amnesia to its culture (e.g., Japan's shame culture as opposed to Germany's guilt culture) and national characteristics (Benedict 1946, 222-224; Buruma 1994), whereas those who believe Japan has apologized too much tend to blame its neighbors' nationalist education (Dor 2015). This article does not attempt to disprove these arguments, but to show that there are structural and historical reasons for the German-Japanese contrast and the underdevelopment of reconciliation in Northeast Asia. By examining the South Korean-Japanese and Sino-Japanese relations alongside the European cases, we may be able to better understand these reasons.

The rest of this article proceeds in five sections. Section 2 clarifies the definitions of reconciliation and peace building and elaborates the different states of reconciliation. Section 3 provides a brief description of the five cases. Section 4 explores the processes of reconciliation and peace building, proposes a series of factors that can possibly explain the variations in the degree of reconciliation and the degree of peace, and then examines the five cases to analyze the effects of these factors on the results. The last section, Sect. 5, concludes.

\section{Reconciliation and Peace Building}

Before proceeding to the cases, we need to clarify some concepts. The English literature on reconciliation covers domestic politics more than international politics, and the concept of reconciliation mainly evolved from studies of intrastate reconciliation. Scholars typically understand reconciliation "as part of a forgiveness process characterized by truth telling, redefinition of the identity of the former belligerents, partial justice, and a call for a new relationship" and believe that it is conducive to the building of a persistently stable social order (Long and Brecke

\footnotetext{
${ }^{3}$ Regarding the selection bias problem, see Geddes (1990).
} 
2003, 3). Bar-Tal and Bennink (2004) examine reconciliation in two aspects, as the outcome and as the process. According to Bar-Tal and Bennink (2004, 16), "stable and lasting peace is characterized by mutual recognition and acceptance, invested interests and goals in developing peaceful relations, as well as fully normalized, cooperative political, economic, and cultural relations based on equality and justice, nonviolence, mutual trust, positive attitudes, and sensitivity and consideration for the other party's needs and interests." These characteristics can be divided into structural elements which peacemaking focuses on and psychological elements which reconciliation focuses on (Bar-Tal and Bennink 2004, 16-19). They also examine reconciliation as a process, stating: "[i]t encompasses psychological changes of motivations, goals, beliefs, attitudes, and emotions, which are reflected in structural changes; these, in turn, facilitate the process of reconciliation" (24). In sum, Bar-Tal and Bennink juxtapose reconciliation with peacemaking by delimiting the former to psychological elements and processes and the latter to structural elements and processes, and according to them reconciliation and peacemaking together lead to stable and lasting peace.

He $(2009,13)$ defines deep interstate reconciliation as being comprised of "two key components-stable peace and an amicable atmosphere-that cover both intergovernmental and people-to-people relationships." For $\mathrm{He}(2009,14)$, while stable peace pertains to official relationship which is about institutions, an amicable atmosphere is related to people-to-people relationship which is more about emotions and interactions. The differences between Tar-Tal and Bennink's conceptualization and He's are: (1) while the former confines reconciliation to the psychological elements and processes, the latter broadens it to include structural, institutional and psychological elements and processes; and (2) while for the former, stable peace is the result of both peacemaking and reconciliation, the latter defines stable peace as a component of a broadened reconciliation.

George (2000, 12-13) defines three categories of peace in international relations: (1) precarious peace, referring to a relationship between two states which is "little more than a temporary absence of armed conflict;" (2) conditional peace, referring to a more secure relationship maintained by general, not immediate, military deterrence; and (3) stable peace, referring to a situation in which the use or threat of military force is out of states' consideration. Similarly, Miller (2000) defines three types of peace, cold peace, normal peace, and warm peace. Corresponding to their typologies, He (2009: 15-20) outlines three categories of reconciliation-nonreconciliation, shallow reconciliation, and deep reconciliation-by considering the intergovernmental dimension measured by mutual expectation of war, national recognition, and economic interaction as well as the popular dimension measured by the degree of mutual trust, sense of affinity, and others. Tang $(2011,714)$ defines reconciliation as a "process of establishing a warm peace between two former foes" and says, "Reconciliation is peace building, not peace itself." He equates shallow reconciliation to "conditional/normal peace" and distinguishes between shallow and deep reconciliations by stating that in the former conflict is "thinkable" and in the latter conflict is "unthinkable." While Tang deserves commendation for limiting reconciliation to denoting a process and distinguishing between peace building 
and peace itself, we believe that both He and Tang have broadened the concept of reconciliation too much by defining reconciliation with different states of peace and equating reconciliation to peace building whereas Bar-Tal and Bennink have defined reconciliation too narrowly by limiting it to psychological process. Instead, we should distinguish between reconciliation and peace building. In its most fundamental sense, reconciliation concerns how two countries deal with their unhappy past; it is a process in which two former foes reach agreement on perceiving and treating their inimical history. Peace building denotes the actions to upgrade the state of peace; it is the process of reducing the probability of war between two countries significantly. Reconciliation is one of the mechanisms that lead to changes in the state of peace, yet it is not peace building itself. Besides reconciliation, peace building can result from other processes, such as state realignment, democratization, building of international institutions, and so on. Admitting reconciliation as an important mechanism for the emergence of deep peace does not need to negate the effects of other variables on peace building. As the studies on security communities by scholars including Acharya (2001), Adler and Barnett (1998), and Kupchan (2010) find, the degree of peace does not always reflect the degree of reconciliation. If we treat them equivalent to each other, we may miss the possibility of clarifying the path of causation that connects them.

While we can follow the George, Miller, and Tang's definitions of three types of peace-namely precarious/cold peace, conditional/normal/shallow peace, and stable/warm/deep peace, we can define three states of reconciliation-namely nonreconciliation, shallow reconciliation, and deep reconciliation-in a way distinctive from He's. While nonreconciliation means a relationship without rapprochement between the former foes, shallow reconciliation refers to a relationship between former adversaries characterized by such actions as words of apology from the perpetrator, negotiation on war reparation, and forgiving gestures from the victim. By comparison, deep reconciliation refers to a relationship characterized by common narration of history, de-sensitization of historical issues, and restoration of affection between two nations. As Fig. 1 shows, compared to the symbolic, verbal expressions of apology and forgiveness between political elites of two nations, deep reconciliation not only requires the expansion of mutual understanding of history from political elites to the society in the horizontal dimension, but also the upgrading of relationship from one characterized by discrete gestures of apology and forgiveness to more institutionalized and deeper mutual understanding and affectionate restoration in the vertical dimension. Generally speaking, only through deep reconciliation do common historical narrative and identity change that go beyond ethnocentrism become possible. By distinguishing between reconciliation and peace building and defining three states of peace and three states of reconciliation, we may be able to clarify the process of reconciliation and the process of peace building in Sect. 4. 


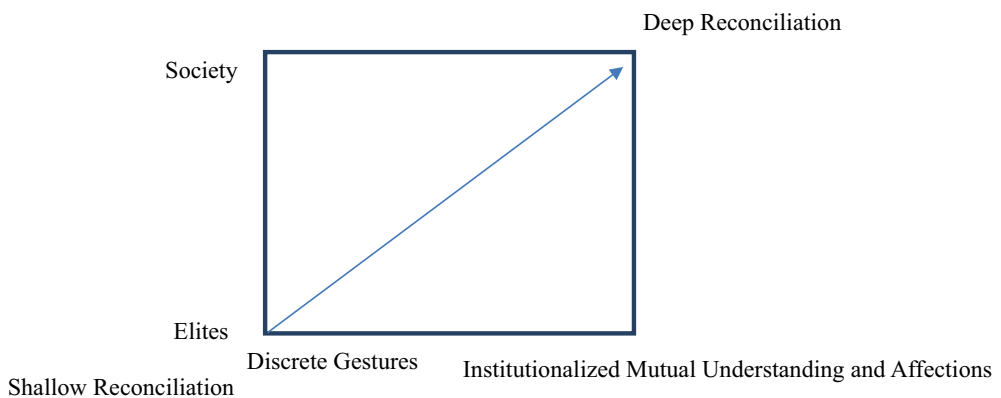

Fig. 1 Shallow reconciliation and deep reconciliation

\section{Description of Cases}

In this section, we select five dyads which have experienced belligerency or enmity-France and Germany, Poland and Germany, Poland and the Soviet Union (Russia), South Korea and Japan, and China and Japan-and describe their unhappy pasts as well as their efforts to reconcile with each other.

\subsection{Unhappy Pasts}

These five pairs of countries have historical memories of war or brutal colonial rule, which require reconciliation and peace building.

France and Germany have had a long history of rivalry. From 1870 to 1945, France and Germany experienced three large-scale wars. In particular, during the World War II, France was defeated by Nazi Germany in weeks, and it had to sign an armistice agreement with the latter, resulting in one half of its territory being occupied and the founding of Vichy France as the Nazi's puppet. From 1941 to 1945, 650 thousand French people were sent to military factories to be forced labor, 76 thousand French Jews were sent directly to concentration camps-only $3 \%$ of them survived - and about 600 thousand French men and women lost their lives on the battlefields or under the Nazi regime (Lind 2008, 104).

In history, Poland's relations with its two major neighbors, Russia and Germany, were fraught with blood and tears. Poland was partitioned in 1772, 1793, and 1795, with Russia participating in all three of them and Prussia participating in the first two. From 1795 to 1918, Poland was not on the map for 123 years. Poland regained its independence at the end of World War I, and it managed to exist for only 21 years before being partitioned again by Germany and the Soviet Union in 1939. During the World War II, Poland lost about 6 million lives, equal to $22.2 \%$ of its population before the war, half of them being Jews (He 2009, 47). At the end of World War II, Poland's borders were redrawn: part of its territory on the East became the territory of the Soviet Union, and part of Germany's territory was transferred to Poland in compensation. As a result, Poland bordered the newly founded East Germany with the Oder-Neisse line, and many Germans who lived on the land transferred to Poland were expelled to West Germany. Considering that 
West German government in Bonn did not recognize the Oder-Neisse line as the permanent border between Poland and Germany until 1970, Poland perceived Bonn as a major rival that threatened its survival during much of the Cold War.

In its long history of being invaded, partitioned, and occupied, Poland's experiences of resisting foreign aggressions, particularly those from Russia, have become an important part of its national memories. In 1939, 3 weeks after Germany invaded Poland, the Soviet Union declared that Poland no longer existed, and it swiftly invaded and occupied Poland. During the Soviet occupation, many Polish elites were purged as "bourgeoisie anti-revolutionaries." In the spring of 1940, the Soviet Union executed over 20 thousand Polish military officers in Katyn, which later became a deep scar in the Polish-Soviet (Russian) relations. Although the Soviet Union defeated the Nazi Germany and acted as the liberator of Poland at the end of World War II, its dominance on postwar Poland has also inflicted pain on the Poles.

As for the bilateral relations between South Korea and Japan, Japan imposed repressive colonial rule on the Korean Peninsula from 1910 to 1945, forcing many Koreans to change their names to Japanese ones, their language to Japanese, and even their religion to Shinto. During Japan's wars against China and other Asian countries, it sent about 750 thousand Koreans to Japan and other countries as forced labor, forced about 200 thousand Korean women to be military sex slaves known as "comfort women," and mobilized thousands of Koreans to fight on the battlefields (Lind 2008, 28). Such sufferings came to an end with Japan's defeat in 1945.

China and Japan have been in constant geopolitical competition since both nations encountered the advent of Western powers in the mid-nineteenth century. The Japanese aggression starting from the Mukden Incident on 18 September 1931 — in which Japan invaded Manchuria in the northeast of China — and ending in 1945 had resulted in the loss of about 35 million Chinese lives, with 930 cities being occupied and 26 out of the 30 provinces being engulfed into the war (He 2009, 117-118). In particular, the Nanking Massacre in December 1937 and the Unit 731 experiments on humans have become horrible war memories among the Chinese people.

\subsection{Different States of Reconciliation and Peace}

Although these dyads of countries have unhappy pasts and animosity that need to be resolved, they are in different states of reconciliation and states of peace. In this sub section, we briefly review how they have reached their current states of reconciliation and states of peace. We describe the cases in the order set by the previous sub section.

Transforming themselves from foes to friends, France and Germany have made their bilateral relations a benchmark for reconciliation. In the post-WWII years and 1950s, though German politicians tended to view Germans themselves also as victims of the Nazi and their rare apologies were mostly exculpatory, the West German government "acknowledged and accepted responsibility for the Nazi-era crimes" and paid reparation to victims of the war (an example was the 1952 Luxemburg Agreement) (Lind 2008, 102, 108-126). German conservative 
politicians did not deny the Nazi crimes. Viewing themselves as victims, they criticized the Nazi, which was possibly the result of the defeat and collapse of the Nazi regime. For example, Western German Chancellor Konrad Adenauer stated to the Bundestag in 1951 that most Germans were "aware of the immeasurable suffering brought to the Jews in Germany and in the occupied territories in the era of National Socialism" and that the "unspeakable crimes... require moral and material restitution" (Herf 1997, 282). Starting from the 1950s, to eradicate the possibility of conflict, Germany and France actively pushed for regional integration to deepen their economic and diplomatic cooperation. For example, in 1951, France, Germany, and four other European countries signed the Treaty establishing the European Coal and Steel Community (ECSC). West Germany's active support for postwar European integration and self-restraint in rearming won trust from its neighbors, particularly from France. Moreover, under the democratic political system, the ascendance of Leftist politicians drove the German public to reflect on the warring past. After the left-wing Social Democratic Party gained power in the late 1960s, the German government increasingly expressed contrition for the Nazi crimes in its official speeches. As a result, starting from the 1960s, France and Germany have reached mutual understanding of their unhappy pasts. When it came to the end of the Cold War, more and more people in both countries had developed a strong identity as Europeans (Checkel 2001).

For France and Germany, they entered shallow peace in the early 1950s marked by the establishment of ECSC in 1951, and they entered shallow reconciliation at roughly the same time symbolized by West German government's paying reparation to victims of the Nazi crimes. And France and West Germany achieved deep reconciliation and deep peace by late 1960s when the Social Democratic leaders' contrition for the Nazi aggression increasingly drew the French and German understandings of history closer. By 1965, according to a French public opinion poll, West Germany was ranked as the best friend of France, gaining $20 \%$ of the respondents' votes (Yeong 2013). The successful reconciliation between France and Germany indicates that regional institutions have provided reassurance for former foes so that they no longer view each other as threats, and regime change and democratization in postwar West Germany have paved way for reflections on the war and converging views of history.

During the Cold War, the international structural conditions defined the PolishGerman relations as confrontational and inimical. Moreover, there were territorial disputes between the two countries because of the issue of the Oder-Neisse line and the expellee issue. Nonetheless, their bilateral relations came to a thaw in late 1960s when Willy Brandt became Chancellor of West Germany. Considering the geopolitical reality in Europe, Brandt was convinced that the reunification of Germany would be impossible unless West Germany improved its relations with East European countries. He developed his Neue Ostpolitik (New Eastern Policy), seeking rapprochement with East Germany, Poland, the Soviet Union, and other Socialist countries. In August 1970, West Germany and the Soviet Union signed the Treaty of Moscow to normalize their relations in which the former recognized de facto the Oder-Neisse line as Germany's border with Poland but insisted on its position for future reunification of Germany. Brandt's falling to his knees in front of 
the monument in remembrance of the victims of the Warsaw Ghetto Uprising in December 1970 brought a shock to Polish people and the rest of the world. It transformed Poles' perception of West Germany. West Germany also signed the Treaty of Warsaw with Poland making similar statements about the Oder-Neisse line and the reunification issue (Phillips 2001). Poland and Germany formed a common textbook committee in 1970 and started common historical research, and the committee proposed common opinions on 26 historical and geographical issues in 1976 (He 2009, 79-81). Right after Brandt's kneeling, however, the majority of West Germans believed that his action was an exaggeration, and his decision to recognize the western Polish border was heavily criticized (Engert 2016, 40), which indicated that it would take years for the reconciliation to deepen and consolidate. Furthermore, despite the improvement of their bilateral relations, neither Poland nor West Germany could disregard the Cold War structure and the possibility of war. After the Soviet Union invaded Afghanistan in 1979 and Warsaw responded to the Polish Solidarity Union Movement by imposing martial law, the Polish-German relations entered a stage of stagnation. Although Brandt signed the Treaty of Warsaw with Poland confirming the postwar border, the conservative Chancellor Helmut Kohl did not accept the legality of the border until 1990 (Friedman 1990). Germany after reunification inherited its position from West Germany on the issue of history and continued to uphold common historical research and textbook examination with Poland. The two sides reached deep reconciliation in the postCold War era. According to a poll conducted in 1994, $61 \%$ of Poles believed they should forgive Germans for their crimes in World War II (Nasalska 2000, 56). After its democratization, Poland adopted a Westernization-oriented foreign policy. It joined the North Atlantic Treaty Organization (NATO) in 1999 and the European Union (EU) in 2004. Generally speaking, Poland and Germany entered the state of deep peace in the late 1990s and early 2000s.

Poland and West Germany entered shallow peace in 1970, when they signed treaty to deal with their territorial disputes and to normalize their relations. They entered shallow reconciliation roughly at the same time, when Brandt fell to his knees to symbolize the German contrition. And as mentioned above, they achieved deep reconciliation in the 1990 s and deep peace in late 1990s and early 2000s. The process of Polish-German reconciliation indicates that such factors as postwar political arrangements (e.g., territorial dispute), alliance (the Cold War structure and its collapse), and regional institutions (e.g., NATO and EU) can affect the process of reconciliation, and that these factors also have great impacts on the degree of peace between states.

Compared to its relations with Germany, Poland's relations with the Soviet Union (Russia) have shown a different trajectory. During the Cold War, as a Warsaw Pact member and a member of the Council for Mutual Economic Assistance (Comecon), Poland was "Stalinized," and its cooperation with the Soviet Union was highly institutionalized (Applebaum 2012). The history of the bilateral relations between Poland and the Soviet Union was narrated in terms of panSlavism and as "friendship of the people" (Behrends 2009). Such a myth, however, was based on suppression of alternative narratives. A number of historical issues including the Katyn Massacre became taboo for scholarly research and public 
discourse. While political elites from both countries reached certain tacit agreement on historical issues, the societies had no freedom to discuss sensitive ones. As a result, Poland and the Soviet Union failed to enter shallow reconciliation, not to say deep reconciliation. Moreover, relying on its coercive military power, the Soviet Union never hesitated to intervene into Poland's internal affairs when necessary. Therefore, despite its institutionalized cooperation with the Soviet Union, Poland was nothing but a satellite state of the latter. For example, Wladyslaw Gomulka, First Secretary of the Polish Workers' Party, was ousted by the Soviet Union in 1948 due to his insistence on Polish way, and he was further imprisoned in 1951. During the Polish October in 1956, when the Soviet leader Nikita Khrushchev negotiated with the Polish leaders, he even commanded the Soviet army to coerce the Polish leaders. Similarly, during the Polish Crisis in early 1980s, the Soviet Union exerted great pressure on the Polish government, ordering it to impose martial law on workers' movements. As such, we can conclude that Poland and the Soviet Union achieved only unstable shallow peace during the Cold War.

After Gorbachev became the Soviet leader, the relations between the Soviet Union and Poland started to change. In 1990, Gorbachev not only officially admitted that the Soviet secret police committed the Katyn Massacre, but also acknowledged the existence of the secret protocols of the German-Soviet Nonaggression Pact which divided Eastern Europe including Poland into German and Soviet spheres of influence. The implosion of the Soviet Union in 1991 further changed the relations between the two countries. In October 1992, Russia handed a copy of the secret documents related to the Katyn Massacre to Poland, and Russian President Boris Yeltsin apologized for what the Soviet Union had done to Poland. After the transformation of Poland's domestic political system and the realignment of East European countries in late 1980s and early 1990s, the issue of history still has potential to trouble the bilateral relations between Poland and Russia. In the first decade of this century, historians from both countries did work together seeking common understanding of their history and produced some important products (e.g., Rotfeld and Torkunov 2010). In recent years, however, the geopolitical tensions related to the Ukraine Crisis have greatly limited the space for common research on historical issues (Bielansky 2015, 70-73). Instead, the issue of history can sometimes even cause diplomatic arguments (Associated Press 2015). Under the shadow of the Ukraine Crisis, Poland has perceived greater threat from Russia, and it has increased its security dependence on NATO (Klus 2014; Emmot and Siebold 2016). In sum, Poland and Russia have hardly gone beyond shallow peace.

Regarding the Polish-Soviet (Russia) relations, both countries lacked proper political environment to seek truth during the Cold War, hence they did not enter shallow reconciliation until early 1990s, when the Soviet Union acknowledged the Katyn Massacre and the existence of the secret protocols of the German-Soviet Nonaggression Pact. Nonetheless, given that Poland and the Soviet Union were in the same alliance for over four decades, and the two countries had institutionalized cooperation most of the time during the Cold War, we arguably believe that they entered shallow peace in early 1950s. Due to the Soviet Union's strong desire to control its satellite states and the latter's nationalist sentiment, however, the shallow peace was not stable. After the end of the Cold War, even though the two countries 
made great progress in reconciliation, there is still a long way to go for them to reach deep reconciliation. As for their security relations, in view of the recent tensions and fear resulting from the Ukraine Crisis, we can conclude that Poland and Russia have not gone beyond shallow peace. The positive effect of progress in reconciliation on peace building has been offset by the effect of Poland's change of alliance membership. The trajectory of Polish-Soviet (Russian) reconciliation indicates that while regime change for the perpetrator and democratization in both countries were conducive to reconciliation, alliance has had a defining impact on the process.

In the post-WWII years, though the United States imposed democratic reforms and a Pacifist constitution on Japan, its occupation policies in effect encouraged Japan to have amnesia for its crimes in World War II and even to glorify its past (Benfell 2002). The start of the Cold War and the Korean War further allowed Japan to exculpate itself: many imprisoned war criminals were released, reparations were waived, wrongdoings were covered or glorified, etc. (Lind 2008, 31-32). South Korea and Japan did not normalize their relations until 1965 mainly because Japan refused to apologize for its colonial rule on South Korea. Starting from late 1950s and early 1960s, Tokyo gradually attempted to improve its relations with Asian countries through "apology diplomacy" so as to change its isolation in the region. In 1965, then Japanese Foreign Minister Shiina Etsusaburo visited South Korea and offered Japan's first apology to the latter, which cleared the major obstacle to the normalization of bilateral relations. Besides expressing regret and remorse on its colonial rule, Tokyo offered 300 million US dollars in grants and more business loans to South Korea so that the latter relinquished further demand for reparation (Lind 2008, 47). The South Korean-Japanese rapprochement was partly due to the US pressure and South Korean leaders' need for development resources (Cha 1996; Lind 2008, 42). The South Korean-Japanese bilateral relations improved rapidly in the 1980s. After the end of the Cold War, along with South Korea's democratization and the end of the long Liberal Democratic Party (LDP) monopoly of ruling power in Japan, how to face history became an increasingly important issue for the two nations. In 1993, the Japanese government admitted in a report that its military had forced Asian and European women to work as sex slaves during World War II (Sturngold 1993). In 1995, then Japanese Prime Minister Tomiichi Murayama offered apology to all the wartime "comfort women," which was resented by some conservative politicians from the Liberal Democratic Party. In the past two decades, the South Korean-Japanese relations have often been troubled by such issues as "comfort women," Japanese officials' visits to the Yasukuni Shrine, and the territorial dispute revolving around the Liancourt Rocks (Dokdo in Korean and Takeshima in Japanese). As a result of the US pressure to forge a solid bloc to counter the rise of China, the South Korean government and the Japanese government reached an agreement on the "comfort women" issue in December 2015. However, the two nations still have a long way to go for deep reconciliation.

Since the Cold War years, South Korea and Japan have been put under the US's wings as key states in its hub-and-spoke alliance system. Thus, their bilateral relations entered shallow peace in the 1950s, despite the territorial dispute and hostility between them. Although South Korea and Japan accomplished shallow reconciliation in 1965, 
they have been engaged in constant debates about Japan's responsibility for its colonial rule and aggressions since the early 1990s. Notwithstanding frequent backlashes from conservative Japanese politicians, such debates generally have been conductive to truth telling and reconciliation. Nonetheless, there is still a long way for the two countries to reach deep reconciliation. That said, the degree of peace between South Korea and Japan is higher than the degree of reconciliation between them due to the existence of the United States as their common ally. The South Korean-Japanese relations indicate that such factors as regime change for perpetrator and alliance have had great impacts on the process of reconciliation, and that alliance is also very important for the degree of peace.

Finally, let us look at the Sino-Japanese relations. After the founding of the People's Republic of China (PRC) and the Kuomintang's retreat to Taiwan in 1949, the PRC and Japan belonged to different camps of the Cold War. Both authorities in Beijing and Taipei were excluded from the San Francisco Peace Conference, and Japan later signed a peace treaty with the Kuomintang regime in Taiwan, with the latter relinquishing its demand for war reparation in exchange for Japan's recognition of Taipei as the sole representative of China. Up until early 1970s, Japan had never apologized or provided war reparation to the PRC. The rapprochement between China and the United States in early 1970s brought a "Nixon shock" to Japan, and Japanese politicians such as Kakuei Tanaka felt great urgency to normalize relations with China. When China and Japan established diplomatic relations in 1972, their joint communiqué stated that "[t]he Japanese side is keenly conscious of the responsibility for the serious damage that Japan caused in the past to the Chinese people through war, and deeply reproaches itself" and that "[t]he Government of the People's Republic of China declares that in the interest of the friendship between the Chinese and the Japanese peoples, it renounces its demand for war reparation from Japan" (Ministry of Foreign Affairs of Japan 1972). Since 1979, Japan has provided China with official development assistance (ODA), which amounts totally to about 3.3164 trillion yen (equivalent to USD 32.5 billion at the 2016 exchange rate) in loan aid, 157.2 billion yen (equivalent to USD 1.54 billion) in grant aid, and 181.7 billion yen (equivalent to USD 1.78 billion) in technical cooperation (Ministry of Foreign Affairs of Japan 2016). In 1980s, a number of issues related to historical remembrance emerged: the history textbook issue, Japanese officials' pilgrimage to the Yasukuni Shrine, etc. After the end of the Cold War and the collapse of the Soviet Union, the United States actively shaped the international system toward unipolarity and upgraded the US-Japanese security cooperation. From the perspective of the US-Japan alliance, China changed from a semi-ally against the Soviet Union during the Cold War to a potential threat in the post-Cold War era. Moreover, China's ascension in material power in the first decade of this century witnessed a drastic decline of Japanese's public affinity for China (Linley 2013). At the same time, the rise of nationalism among the Chinese people since the 1990s made them more sensitive to Japan's attitude toward its past aggression and increasingly intolerant to any diplomatic compromise from the Chinese government.

It is noteworthy that Japanese leaders have apologized to South Korea for historical issues much more frequently than to China. Japanese Prime Ministers including 
Yasuhiro Nakasone, Toshiki Kaifu, Kiichi Miyazawa, Tomiichi Murayama, Nato Kan and Emperor Akihito have expressed "regret," "remorse," or "apology" to South Korea. To China, however, besides the "self-reproach" in the joint communiqué that established diplomatic relations between China and Japan, other occasions of apology were: Emperor Akihito's “regret" for the unfortunate history when meeting Chinese Premier Li Peng in 1989 and Prime Minister Junichiro Koizumi's "heartfelt apology and mourning" to Chinese victims of the war of aggression at his visit to the Museum of Chinese People's War of Resistance against Japan (Ministry of Foreign Affairs of China 2000; Ministry of Foreign Affairs of Japan 2001). In addition, Japanese leaders have also expressed apology to its Asian neighbors in general. The most notable apology was given by Japanese Prime Minister Tomiichi Murayama on 15 August 1995 (Ministry of Foreign Affairs of Japan 1995). Considering the frequent tensions caused by Japanese officials' pilgrimage to Yasukuni Shrine and the disputes on historical issues, we believe that the China and Japan have achieved only shallow reconciliation.

Generally speaking, as China and Japan established diplomatic relations in 1972, they achieved shallow reconciliation and reached shallow peace. Nonetheless, their relations are still far from deep reconciliation and deep peace. In recent years, due to the constant flare-up of tensions over the Diaoyu/Senkaku Islands and the intensification of geopolitical competition between China and the US-Japanese alliance, the state of peace in East Asia is sometimes in jeopardy. The trajectory of the Sino-Japanese relations indicates that such factors as postwar political arrangements regarding territory and regime legitimacy, alliance that defines the regional geopolitical landscape, and whether the perpetrator state has undergone regime change have great impacts on the process of reconciliation.

Based on the above review of the five dyads, Table 1 summarizes the states of reconciliation and the states of peace for them as well as when they reached these states.

Table 1 States of reconciliation and peace and their starting dates

\begin{tabular}{|c|c|c|c|c|}
\hline Case & $\begin{array}{l}\text { Shallow } \\
\text { peace }\end{array}$ & $\begin{array}{l}\text { Shallow } \\
\text { reconciliation }\end{array}$ & Deep reconciliation & Deep peace \\
\hline $\begin{array}{l}\text { Franco- } \\
\text { German } \\
\text { relations }\end{array}$ & $1950 \mathrm{~s}$ & $1950 \mathrm{~s}$ & Late $1960 \mathrm{~s}$ & Late $1960 \mathrm{~s}$ \\
\hline $\begin{array}{l}\text { Polish-German } \\
\text { relations }\end{array}$ & 1970 & 1970 & $1990 \mathrm{~s}$ & $\begin{array}{r}\text { Late } 1990 \mathrm{~s} \text { to } \\
\text { early } 2000 \mathrm{~s}\end{array}$ \\
\hline $\begin{array}{l}\text { Polish-Soviet } \\
\text { (Russian) } \\
\text { relations }\end{array}$ & $\begin{array}{l}\text { Early } 1950 \text { s, } \\
\text { but not } \\
\text { stable }\end{array}$ & Early 1990s & $\begin{array}{l}\text { Reconciliation proceeded in } 1990 \text { s, } \\
\text { but not yet deep reconciliation }\end{array}$ & Not yet \\
\hline $\begin{array}{l}\text { South Korean- } \\
\text { Japanese } \\
\text { relations }\end{array}$ & $1950 \mathrm{~s}$ & 1965 & $\begin{array}{l}\text { Reconciliation proceeded since the } \\
1990 \text { s, but not yet deep } \\
\text { reconciliation }\end{array}$ & $\begin{array}{l}\text { Between } \\
\text { shallow and } \\
\text { deep peace }\end{array}$ \\
\hline $\begin{array}{l}\text { Sino-Japanese } \\
\text { relations }\end{array}$ & 1972 & 1972 & Not yet & Not yet \\
\hline
\end{tabular}




\section{Analysis of the Cases}

In this section, we compare the cases reviewed above to explore the processes of reconciliation and peace building, and then propose a series of factors that can possibly explain the variations in degree of reconciliation and degree of peace.

\subsection{General Observations}

Based on the above description of the five cases, we can make some observations. First, these five dyads entered the state of precarious peace around similar time, the end of World War II. Among the five cases, there are three ways to achieve precarious peace. The first way is that the perpetrator is defeated in war. The Franco-German relations, the Sino-Japanese relations, the South Korean-Japanese relations fall into this category. The second way is that the perpetrator and the victim and their allies form balance of power. The Polish-German relations fall into this category. The third way is that the perpetrator dominates the victim. The Polish-Soviet relations fall into this category, notwithstanding their relations show some particular characteristics. The Soviet Union was both an aggressor against Poland's sovereignty and a liberator who defeated Germany and restored Poland's statehood. After these pairs of countries reached precarious peace, they might proceed to shallow reconciliation. Without a certain degree of peace, reconciliation is impossible.

Second, it is noteworthy that the Polish-Soviet relations and the South KoreanJapanese relations entered shallow peace prior to shallow reconciliation, whereas the Franco-German relations, the Polish-German relations, and the Sino-Japanese relations all entered shallow peace and shallow reconciliation roughly at the same time. The former two dyads entered shallow peace ahead of shallow reconciliation mainly because their shallow peace was imposed, either by the preponderant power in the dyad (e.g., the Soviet Union for the Polish-Soviet relations) or by an external preponderant power (e.g., the United States for the South Korean-Japanese relations). Furthermore, by comparing the Polish-Russian relations to the South Korean-Japanese relations, we can find that while currently the former's degree of reconciliation is higher than its degree of peace, the latter's degree of reconciliation is less than its degree of peace. This is because Poland and Russia are not in the same alliance, whereas South Korea and Japan are both the US's ally. It is evident that reconciliation is different from peace building, and that the degree of reconciliation does not necessarily correspond with the degree of peace, as is mentioned above in Sect. 2.

Third, as mentioned in Sect. 2, the transition from shallow reconciliation to deep reconciliation is a complex process that involves at least two dimensions of changes: one dimension is the expansion of mutual understanding of historical issues from political elites to the society, and the other dimension is that the relationship is upgraded from one characterized by discrete gestures to one based on institutionalized mutual understanding and affections. While the five dyads entered shallow reconciliation for different reasons (for example, the important role of the US and 
political leaders for the South Korean-Japanese relations, the development of international structure and coalition for the Sino-Japanese relations, ${ }^{4}$ and so on), it is the question "why some former adversaries have achieved deeper reconciliation than others" that is of much more theoretical importance. Based on the description of the cases in Sect. 3, we propose a series of factors that may explain the difference in degree of reconciliation: postwar political arrangements (whether there are disputes regarding territory, regime legitimacy, and so on), regime change for perpetrator, alliance (whether the perpetrator and the victim are in the same alliance in the postwar era), regime type (whether the perpetrator and the victim are both democracies), and regional institutions. These factors can not only affect the degree of reconciliation, but also, together with the degree of reconciliation, affect the degree of peace.

Based on these general observations, we can illustrate the processes of reconciliation and peace building in Fig. 2. In this figure, the arrows denote the process, whereas the oval arrows denote facilitating effects. Figure 2 illustrates that starting from precarious peace (where there is no reconciliation), there can be two processes, one is the peace building process on the left, and the other is the reconciliation process on the right. Factors such as postwar political arrangements, regime change for perpetrator, alliance, regime type, and regional institutions all have facilitating effects on both the reconciliation process and the peace building process. Moreover, the process of reconciliation can affect the process of peace building together with other factors mentioned above.

\subsection{Explaining Variation in Degree of Reconciliation}

Why have some former adversaries achieved deep reconciliation whereas others fail to go beyond shallow reconciliation? What explain the difference in degree of reconciliation among these cases? In this subsection, we examine the cases by assessing the values of the factors proposed above as well as the degree of reconciliation. In this analysis, the dependent variable is the degree of reconciliation, and all the above-proposed factors including postwar political arrangements, regime change for perpetrator, alliance, regime type, and regional institutions are independent variables.

Regarding the dependent variable (degree of reconciliation), besides shallow reconciliation and deep reconciliation, we can add a third value, intermediate reconciliation, for the variable. It refers to the state of reconciliation roughly in the middle of shallow reconciliation and deep reconciliation. Based on their degrees of reconciliation, the five cases can be divided into three categories: deep reconciliation, such as the Franco-German relations and the Polish-German relations; intermediate reconciliation, such as the Polish-Russian relations and the South Korean-Japanese relations; and shallow reconciliation, such as the Sino-Japanese relations. Although Poland and Russia have made great progress in truth telling after the end of the Cold War, they still fall short of deep reconciliation due to their low levels of emotional healing and relationship restoration. As for the South Korean-

\footnotetext{
${ }^{4}$ For more information, see Katayama (2011, 648-651).
} 


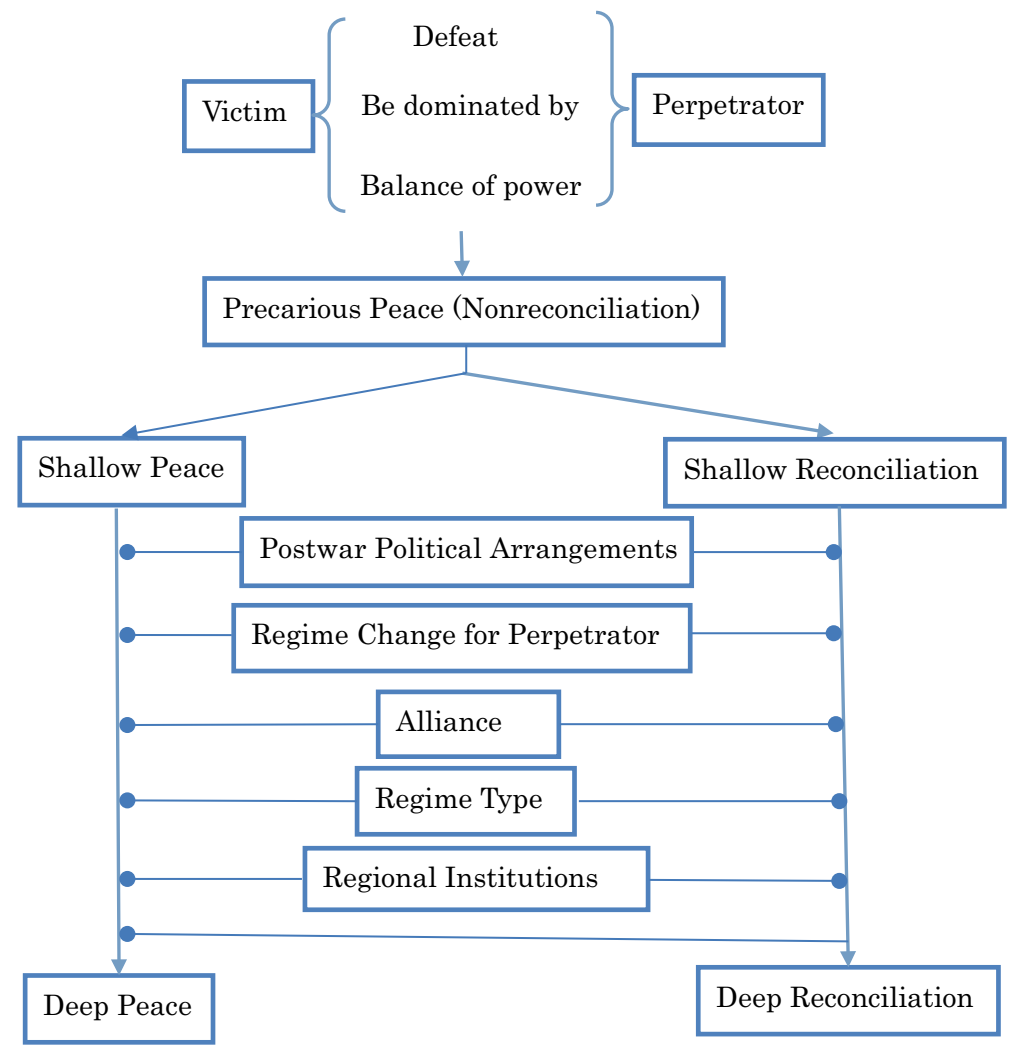

Fig. 2 Processes of reconciliation and peace building

Japanese relations, though the two governments have officially solved their dispute on the issue of "comfort women," there are still uncertainties whether the intergovernmental agreement will be accepted by both societies. Meanwhile, other issues such as Japanese officials' visits to the Yasukuni Shrine and the Liancourt Rocks dispute can still hit the political nerves of the two countries. As for the SinoJapanese relations, they still have shallow reconciliation.

Then, let us look at the values of the independent variables. The first independent variable is postwar political arrangements, particularly referring to whether there are disputes related to territory and regime legitimacy. Generally speaking, France and Germany did not have disputes in this aspect. France's success in integrating Alsace and Lorraine into the French state after 1945 and its failure to separate the Saar region from West Germany as a result of the Saar statue being rejected in a referendum in 1955 resolved the Franco-German border contestation somewhat evenly, and moreover the borderlands between the two countries even developed into "zones of contact, exchange and openness" in the process of European integration and reconciliation (Hopel 2012). As for Poland and West Germany, on the one hand, Germany was divided into West Germany and East Germany, and reunification of Germany became an important goal for West 
Germany; on the other hand, as part of the postwar arrangements, the PolishGerman border had been redrawn, and West Germany would have territorial dispute with Poland unless it recognized the Oder-Neisse line as the new border. The first aspect of the arrangements gave Germany incentive to cooperate and reconcile with Poland because reunification would be impossible unless West Germany's relations with East European countries came to thaw out. The second aspect of the arrangements, however, created obstacles to reconciliation. As such, regarding postwar political arrangements, the Polish-German relations had both positive and negative aspects, possibly with their effects offsetting each other. For the PolishSoviet (Russian) relations, while Poland lost its Eastern borderland to the Soviet Union, it gained a smaller but more industrialized territory on the West from Germany. Hence, there were both positive and negative aspects for the PolishSoviet relations on postwar political arrangements. With regard to the South Korean-Japanese relations, the ending of Japan's colonial rule on the Korean Peninsula in 1945 and the founding of both South and North Koreas comprised the postwar political arrangements for the relations. Despite the Korean War from 1950 to 1953 on the question of reunification, there were few disputes between South Korea and Japan except the Liancourt Rocks (Dokdo or Takeshima) dispute since the 1950s. As such, for the South Korean-Japanese relations, the value for postwar political arrangements was somewhat negative. Among all the dyads, the SinoJapanese relations have been most troubled by postwar political arrangements. Due to the Chinese Civil War from 1945 to 1949 and the competition for legitimacy and diplomatic recognition between the Chinese Communist Party (CCP) and the Kuomintang (KMT) following the war, China, who fought Japan for the longest and suffered the most, was excluded from the 1951 San Francisco Peace Conference. As a result, Japan was able to take advantage of the China's domestic division to shirk its responsibilities of apology and reparation. Furthermore, the territorial dispute of Diaoyu/Senkaku Islands between China and Japan has also been closely related to postwar political arrangements. The CCP-KMT dispute on regime legitimacy delayed the normalization of relations between the PRC and Japan till 1972, and the Diaoyu/Senkaku Islands dispute still perplexes the bilateral relations.

The second independent variable is regime change for perpetrator. Whether the perpetrator has undergone regime change has a profound effect on its ability to be contrite. Regime change for the perpetrator can pave the way for putting those people responsible for war crimes on trial, questioning the ideology that has glorified war, bringing those who have resisted war to powerful positions, and finally re-directing the country back to the right track. The death of Adolf Hitler and the collapse of Nazi made democratization in West Germany profound and effective, which in turn made its reconciliation with France and Poland much easier. On the contrary, in Japan, despite the political reforms and the adoption of a pacifist constitution, many political and economic elites who had been responsible for its aggressive war managed to retain their positions in the postwar government and business, which had negative impacts on the South Korean-Japanese and SinoJapanese relations. As for the Polish-Soviet (Russian) relations, notwithstanding the perpetrator-the Soviet Union-maintained its dominance for decades after the war, 
the political reforms and regime change in the Soviet Union in early 1990s led to the unveiling of the Katyn Massacre.

The third independent variable is alliance. Under the bipolar international structure, countries from the Eastern bloc rarely succeeded in reconciling with those from the Western bloc. In contrast, countries from the same alliance system are more likely to reconcile with each other. This is particularly true for countries of the Western bloc. France and Germany have been members of NATO and the European regional institutions for decades. South Korea and Japan have not been allies of each other, nor have they been members of any major collective security organization. Nonetheless, they have been both treaty-based allies of the United States. Thus, we can still treat them as being in the same alliance, but they do not have as a high value for this variable as the Franco-German relations. China and Poland's alliance experiences have shown dramatic trajectories. Shortly after the founding of the PRC in 1949, it adopted a foreign policy of "leaning to one side," being a loyal member of the Socialist bloc and fighting Americans in the Korean War. After the SinoSoviet split in late 1950s and early 1960s and particularly when facing the growing Soviet threat in the late 1960s, China made a foreign policy turn for a rapprochement with the United States. From Nixon's visit to China in 1972 to the 1980s, China was a semi-ally of the US and Japan against the Soviet threat. After the end of the Cold War and with the disappearance of Soviet threat, the United States and Japan turned to view China as a potential challenger. Another example of alliance jumper is Poland. From the end of WWII to 1980s, Poland was a member of the Soviet bloc. As a result of its democratic transition starting from 1989, Poland turned to the West, accessing NATO in 1999 and EU in 2004 and now belonging to the same alliance system as Germany. Poland's joining the West led to its distancing itself from Russia, the successor of the Soviet Union.

The fourth independent variable is regime type. Although shallow reconciliation could materialize between states of a closed political system, deep reconciliation is more likely to occur in an open political and social environment. Democracy emphasizes a government's accountability to society and its institutionalized communications with the people. It is conducive to the spreading of reconciliation from political elites to society and the institutionalization of conciliatory mutual understanding between former foes. Some scholars even argue that democratization is the precondition for intrastate reconciliation (Bar-Tal and Bennink 2004, 25). For interstate reconciliation, derived from the democratic peace theory, two countries of democratic system will have more mutual trust, and they are more likely to engage in truth-telling and relationship restoration through open deliberation. We would also like to argue that when the perpetrator is a democracy and the victim is a nondemocracy, it can give the former an excuse to resist contrition and reconciliation. Germany's democratic reform after the end of World War II provided an institutional platform for the left-wing politicians to advocate reflection on the Nazi crimes. For the Poland-German relations, it was not coincidence that the reconciliation between them proceeded rapidly in the post-Cold War era after Poland's political transition. Reconciliation is impossible to progress without free access to truth and free deliberation on historical facts. Russia's political transition to a semi-democracy in the 1990s enabled it to face the Katyn Massacre with 
Poland. For the South Korean-Japanese relations, the growing engagement with historical issues has been part of South Korea's democratization process (Barkan 2012). In contrast, for the Sino-Japanese relations, the difference in political system constrains the quantity and quality of exchanges on history between the two societies.

The last independent variable is regional institutions. Regional institutions can provide security assurance to resolve the fear and mistrust between former foe states and a regional platform for them to interact with each other. They can also exert supervision on state behaviors, so as to reduce the risk for cooperation. In addition, regional institutions can constrain nationalist discourse and sentiment. Among the five cases, for the Franco-German relations, their regional institutions have been the strongest thanks to Europe's growing integration. In contrast, for the South KoreanJapanese and Sino-Japanese relations, their regional institutions have been scarce. For Poland, after its accession to EU, the intensive cooperation in the regional institution has enabled it to consolidate its reconciliation with Germany. For Poland and Russia, after the collapse of the Soviet bloc, there is no regional organization that can resolve their differences. Based on the above review, we can summarize the values of the above-mentioned variables in Table 2 .

From Table 2, we can find that generally speaking there is a relationship between the independent variables (postwar political arrangements, regime change for perpetrator, alliance, regime type, and regional institutions) and the dependent variable (degree of reconciliation). For the Franco-German relations, all the independent variables have positive values, and the value of dependent variable is deep reconciliation. For Polish-German relations, its value for the independent variable "postwar political arrangements" is that it has both positive and negative aspects, its value for the independent variable "regime change for perpetrator" is positive, and its values for the other three independent variables are all "from no to yes." Correspondingly, its value for the dependent variable (degree of reconciliation) is "from shallow to deep." In particular, we find that for the Polish-German relations, the change in degree of reconciliation has coincided with the changes of the values of independent variables including alliance, regime type, and regional institutions from negative to positive.

For the Polish-Soviet (Russian) relations and South Korean-Japanese relations, whose degrees of reconciliation are both intermediate, they have similar values for the independent variables as a whole. For the independent variable "postwar political arrangements," the value of the Polish-Soviet (Russian) relations is roughly neutral with both positive and negative aspects, whereas the value of the South Korean-Japanese relations is "somewhat negative." For the other four independent variables (regime change for perpetrator, alliance, regime type, and regional institutions), the Polish-Soviet (Russian) relations have "from no to (partly) yes" for two of them and "from yes to no" for the other two, whereas the values of the South Korean-Japanese relations for these variables are "no," "mostly no," "mostly yes," "from no to yes," respectively. Considering that the effects of different independent variables might offset each other, it is reasonable that both the two cases have intermediate reconciliation. In contrast, for the Sino-Japanese relations, since the values of all its independent variables are negative, it is not a 


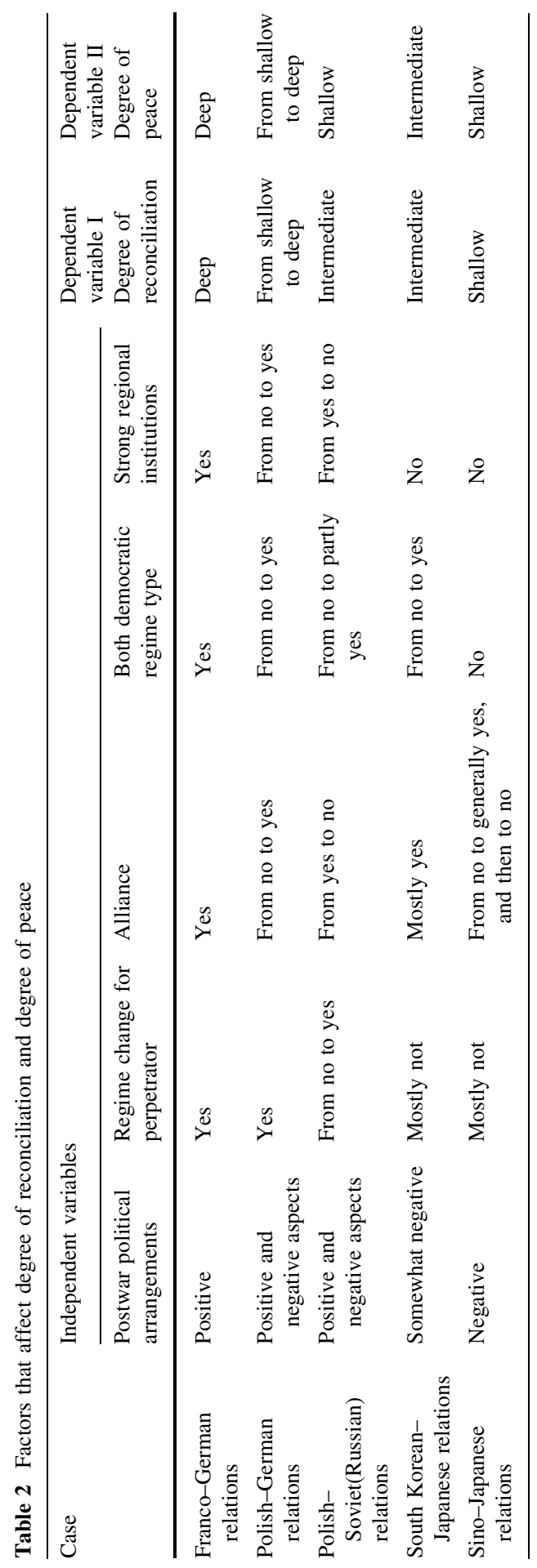


surprise that the two countries have only achieved shallow reconciliation. Based on the results in Table 2, we can conclude that countries with positive values in the independent variables are more likely to proceed from shallow reconciliation to deep reconciliation. That is, although we cannot conduct a quantitative analysis of the cases, we can generally conclude that the above-mentioned factors do have impressive effects on the degree of reconciliation.

\subsection{Explaining Variation in Degree of Peace}

In this subsection, we first assess the degree of peace for the cases, and then use the above-mentioned factors as well as the degree of reconciliation to explain the variation in the degree of peace among the cases. Here the dependent variable is degree of peace, and the independent variables include postwar political arrangements, regime change for perpetrator, alliance, regime type, regional institutions as well as the degree of reconciliation.

On the dependent variable, besides shallow peace and deep peace, we can add a third value intermediate reconciliation, which refers to the degree of peace roughly in the middle of shallow peace and deep peace. Based on the description of the cases in Sect. 3, we can divide them into three categories: deep peace such as the FrancoGerman relations and the Polish-German relations, intermediate peace such as the South Korean-Japanese relations, and shallow peace such as the Polish-Soviet (Russian) relations and the Sino-Japanese relations. Table 2 lists our assessment of the degrees of peace for these cases.

It is noteworthy that while the Polish-Russian relations have intermediate degree of reconciliation, their degree of peace is still shallow in the post-Cold War era. Considering the tensions between NATO and Russia and Poland's fear under the shadow the Ukraine Crisis, this assessment of their degree of peace is sober. Since the end of the Cold War, although both Poland and Russia have experienced great changes in their political systems and certain degree of democratization, they are no longer members of the same alliance, and they share no regional institutions. These changes in independent variables explain why the degree of peace between Poland and Russia is shallow despite their progress in reconciliation. It indicates that the degree of peace not only is affected by the degree of reconciliation, but also depends on other factors such as postwar political arrangements, whether there is regime change for the perpetrator, whether both the perpetrator and the victim have democratic political system, and regional institutions.

It is also the case for other dyads when we look carefully into the evolution of their degrees of peace. For example, although Poland and Germany made rapid progresses in reconciliation in 1970s, the probability of conflict between them still existed due to the confrontation between the Eastern and Western blocs. After Poland and Germany reached deep reconciliation in the 1990s and as Poland joined the NATO in 1999 and the EU in 2004, the two countries entered deep peace in late 1990s and early 2000s. The Polish-German relations indicate that postwar political arrangements, whether belonging to the same alliance system, and whether there exist strong international institutions are not only the independent variables for the degree of reconciliation, but also the independent variables for the degree of peace. 
For the South Korean-Japanese relations, though they still have territorial disputes and the regional institutions in Northeast Asia are weak, the probability of war between them is very low mainly because they share the same important ally the United States. Their common democratic political system also helps to maintain peace between them. The positive effects of alliance and political system offset the negative effects of territorial disputes and of regional institution scarcity. Moreover, we believe that due to the disproportional effect of alliance, the degree of peace for South Korean-Japanese relations is higher than its degree of reconciliation. Last but not least, for China and Japan, due to the Diaoyu/Senkaku Island dispute as a problem of postwar political arrangements, the US-Japanese alliance's hostility to China, the scarcity of regional institutions in Northeast Asia, their difference in political system, and the shallow reconciliation as well, the two countries have reached only shallow peace. In sum, postwar political arrangements, regime change for perpetrator, alliance, regime type, regional institutions, and the degree of reconciliation can all affect the degree of peace.

Although the degree of reconciliation and the degree of peace do not correspond with each other, we can still find a general relationship between the degree of reconciliation and the degree of peace. Except for the Polish-Russian relations, all the other relations' degrees of reconciliation are very close to their degrees of peace. Countries of higher degree of reconciliation tend to have higher degree of peace, which indicates that reconciliation is an important mechanism for peace building. Peace building through reconciliation is an advice that has an empirical foundation. ${ }^{5}$

\section{Conclusion}

In this article, we distinguish between reconciliation and peace building and clarify the different states of reconciliation. To understand why some former adversaries have achieved deeper reconciliation than others, this article examines five cases of reconciliation and peace building in the post-World War II era-the FrancoGerman relations, the Polish-German relations, the Polish-Soviet (Russian) relations, the South Korean-Japanese relations, and the Sino-Japanese relationsand explores the process of reconciliation and the process of peace building. We propose a series of factors including postwar political arrangements, regime change for perpetrator, alliance, regime type, and regional institutions to explain the variations among these cases in the degree of reconciliation and the degree of peace. And we assess the effects of these factors on the degree of reconciliation and the degree of peace. We find that these factors have impacts on the degree of reconciliation, and that together with the degree of reconciliation, they can affect the degree of peace. We also find that while the degree reconciliation and the degree of peace do not necessarily correspond with each other, there is generally speaking a relationship between them. Peace building through reconciliation is a sound advice.

While Germany has set a model for reconciliation, Japan's relations with China and South Korea have often been troubled by their unhappy pasts. It is tempting to

\footnotetext{
5 For a discussion on it, see Lerche (2000).
} 
attribute the pessimistic picture of reconciliation in East Asia to Japanese culture or to the manipulation of nationalist sentiment in China and South Korea. Nonetheless, by placing the Sino-Japanese relations and the South Korean-Japanese relations in a framework of comparative study along with the Franco-German relations, the Polish-German relations, and the Polish-Soviet (Russian) relations, we find that there are structural and historical reasons for the underdevelopment of reconciliation in Northeast Asia. For such factors as postwar political arrangements, regime change for perpetrator, alliance, regime type, regional institutions, we find that the Sino-Japanese relations have mostly negative values, the South Korean-Japanese relations and the Polish-Soviet (Russian) relations have mixed values, and the Franco-German relations and the Polish-German relations have mostly positive values. Therefore, the underdevelopment of reconciliation in Northeast Asia may be a reasonable outcome of a series of structural conditions and historical developments. By further studying these structural and historical reasons, we may be able to better understand, manage, and even deal with some of the diplomatic stalemates among China, Japan, and South Korea when facing historical issues.

Acknowledgments This research is sponsored by the Shanghai Pujiang Program. Chengqiu Wu is also grateful to the Swire Educational Trust for granting him the Swire/Cathay Pacific Scholarship to sponsor his academic visit at St Antony's College, Oxford, during which this research is completed.

\section{References}

Adler, Emanuel, and Michael Barnett. 1998. Security communities. Cambridge: Cambridge University Press.

Acharya, Amitav. 2001. Constructing a security community in Southeast Asia: ASEAN and the problem of regional order. London: Routledge.

Applebaum, Anne. 2012. Iron curtain: The crushing of Eastern Europe, 1944-1956. New York: Random House.

Associated Press. 2015. Russian ambassador says Poland was partly to blame for World War II. New York Times. September 26. http://www.nytimes.com/2015/09/27/world/europe/russian-ambassadorsays-poland-was-partly-to-blame-for-world-war-ii.html?_r=0. Accessed 20 May 2016.

Bar-Siman-Tov, Yaacov (ed.). 2004. From conflict resolution to reconciliation. Oxford: Oxford University Press.

Bar-Tal, Daniel, and Gemma H. Bennink. 2004. The nature of reconciliation as an outcome and as a process. In From conflict resolution to reconciliation, ed. Yaakov Bar-Siman-Tov, 11-38. Oxford: Oxford University Press.

Barkan, Elazar. 2012. Book review for War, Guilt, and World Politics after World War II. http:// historicaldialogues.org/wp-content/uploads/2012/07/Barkan-Review-Berger.pdf. Accessed 1 August 2016.

Behrends, Jan C. 2009. Nation and empire: dilemmas of legitimacy during Stalinism in Poland (1941-1956). Nationalities Papers 37(4): 443-466.

Benedict, Ruth. 1946. The chrysanthemum and the sword: Patterns of Japanese culture. Boston: Houghton Mifflin Company.

Benfell, Steven T. 2002. Why can't Japan apologize? Institutions and war memory since 1945. Harvard Asia Quarterly 6(2): 4-11.

Buruma, Ian. 1994. The wages of guilt: Memories of war in Germany and Japan. New York: Farrar, Straus \& Giroux.

Bielansky, Stefan. 2015. Russia, Poland and the 'New Europe': Inevitable clash? In Beyond Ukraine: EU and Russia in Search of a New Relation, ed. Aldo Ferrari. ISPI REPORT, http://www.ispionline.it/it/EBook/ BEYOND.UKRAINE.2015/BEYOND.UKRAINE_Cap.4_EBOOK.pdf. Accessed 1 May 2016. 
Cha, Victor D. 1996. Bridging the gap: the strategic context of the 1965 Korea-Japan normalization treaty. Korean Studies 20(1): 123-160.

Checkel, Jeffrey T. 2001. Why comply? Social learning and European identity change. International Organization 55(3): 553-588.

Dor, Alexandre. 2015. China's WW2 remembrance: 'Patriotic education' in action. The Diplomat. August 15. http://thediplomat.com/2015/08/chinas-ww2-remembrance-patriotic-education-in-action/. Accessed 1 May 2016.

Emmot, Robin, and Sabin Siebold. 2016. NATO agrees to reinforce eastern Poland, Baltic States against Russia. Reuters. July 8. http://www.reuters.com/article/us-nato-summit-idUSKCNOZN2NL. Accessed 1 August 2016.

Engert, Stefan. 2016. Germany-Israel: A prototypical political apology and reconciliation process. In Apology and reconciliation in international relations: The importance of being sorry, ed. Christopher Daase, Stefan Engert, Michel-Andre Horelt, Judith Renner, and Renate Strassner, 29-50. London: Routledge.

Friedman, Thomas L. 1990. Evolution in Europe; 2 Germanys vow to retain border with the poles. New York Times. July 18. http://www.nytimes.com/1990/07/18/world/evolution-in-europe-2-germanysvow-to-retain-border-with-the-poles.html. Accessed 25 April 2016.

Geddes, Barbara. 1990. How the cases you choose affect the answers you get: Selection bias in comparative politics. Political Analysis 2(1): 131-150.

George, Alexander. 2000. Forward. In Stable peace among nations, ed. Arie M. Kacowicz, Yaacov BarSiman-Tov, Ole Elgstrom, and Magnus Jerneck, 11-18. Lanham: Rowman \& Littlefield Publishers.

He, Yinan. 2009. The search for reconciliation: Sino-Japanese and German-Polish relations since World War II. Cambridge: Cambridge University Press.

Herf, Jeffery. 1997. Divided memory: The Nazi past in the two Germanys. Cambridge: Harvard University Press.

Hopel, Thomas. 2012. The French-German borderlands: Borderlands and nation-building in the 19th and 20th Centuries. European History Online. August 23. http://ieg-ego.eu/en/threads/crossroads/borderregions/thomas-hoepel-the-french-german-borderlands. Accessed 1 Oct 2016.

Katayama, Kazuyuki. 2011. Development of Japan-China relations since 1972. International Journal of China Studies 2(3): 647-679.

Klus, Adam. 2014. Poland on the frontlines of the Ukraine Crisis. New Eastern Europe. November 4. http:// www.neweasterneurope.eu/interviews/1387-poland-on-the-frontlines-of-the-ukraine-crisis. Accessed 20 April 2016.

$\mathrm{Ku}$, Yangmo. 2008. International reconciliation in the postwar era, 1945-2005: A comparative study of Japan-ROK and Franco-German relations. Asian Perspective 32(3): 5-37.

Kupchan, Charles. 2010. How enemies become friends: The sources of stable peace. Princeton: Princeton University Press.

Lerche, Charles. 2000. Peace building through reconciliation. International Journal of Peace Studies 5(2): 61-76.

Lind, Jennifer. 2008. Sorry states: Apologies in International Politics. Ithaca: Cornell University Press.

Linley, Matthew. 2013. Unfriending: Japanese public opinion on China. The Interpreter. January 22. http://www.lowyinterpreter.org/post/2013/01/22/Unfriending-Japanese-public-opinion-on-China. aspx. Accessed 1 April 2016.

Long, William J., and Peter Brecke. 2003. War and reconciliation: Reason and emotion in conflict resolution. Cambridge, Mass.: MIT Press.

Miller, Benjamin. 2000. The international, regional and domestic sources of regional peace. In Stable peace among nations, ed. Arie M. Kacowicz, Yaacov Bar-Siman-Tov, Ole Elgstrom, and Magnus Jerneck, 55-74. Lanham: Rowman \& Littlefield Publishers.

Ministry of Foreign Affairs of China. 2000. Bilateral political relations. November 15. http://www.fmprc.gov. cn/mfa_eng/wjb_663304/zzjg_663340/yzs_663350/gjlb_663354/2721_663446/2722_663448/t15969. shtml. Accessed 3 May 2016.

Ministry of Foreign Affairs of Japan. 1972. Joint communiqué of the government of Japan and the government of the People's Republic of China. September 29. http://www.mofa.go.jp/region/asiapaci/china/joint72.html. Accessed 3 May 2016.

Ministry of Foreign Affairs of Japan. 1995. Statement by Prime Minister Tomiichi Murayama "On the occasion of the 50th anniversary of the war's end." August 15. http://www.mofa.go.jp/announce/ press/pm/murayama/9508.html. Accessed 5 May 2016. 
Ministry of Foreign Affairs of Japan. 2001. Visit to the People's Republic of China by Prime Minister Junichiro Koizumi meeting with President Jiang Zemin. October 8. http://www.mofa.go.jp/region/ asia-paci/china/pmv0110/meet-2.html. Accessed 3 May 2016.

Ministry of Foreign Affairs of Japan. 2016. Overview of official development assistance (ODA) to China. February 1. http://www.mofa.go.jp/policy/oda/region/e_asia/china/. Accessed 5 May 2016.

Nasalska, Ewa. 2000. German-Polish relations in the historical consciousness of polish youths. International Education 11(1): 53-64.

Phillips, Ann L. 2001. The politics of reconciliation revisited: Germany and East-Central Europe. World Affairs 163(4): 171-191.

Rotfeld, Adam D., and Anatoly W. Torkunov (eds.). 2010. White stains-black stains: Difficult issues in Polish-Russian relations, 1918-2008. Warsaw: Polish Institute of International Affairs.

Sturngold, James. 1993. Japan admits army forced women into wartime brothels. New York Times. August 3. http://www.nytimes.com/1993/08/05/world/japan-admits-army-forced-women-into-warbrothels.html. Accessed 15 February 2016.

Tang, Shiping. 2011. Review article: reconciliation and the remaking of anarchy. World Politics 63(4): 713-751.

Yeong, Loke Hoe. 2013. 50 years of the "twin engine": Franco-German reconciliation, European integration and reflections for Asia. Background Brief No. 8. EU Centre in Singapore. http://www. eucentre.sg/wp-content/uploads/2013/06/BB08-50yearstwinengine.pdf. Accessed 15 April 2016.

Chengqiu Wu is an Associate Professor of International Politics at the School of International Relations and Public Affairs (SIRPA), Fudan University, Shanghai, China. He was an academic visitor at St Antony's College, University of Oxford, UK from October 2015 to September 2016. His fields of interest include political economy, international relations of the Asia-Pacific region, and Chinese foreign policy.

Fan Yang is a graduate student at the School of International Relations and Public Affairs (SIRPA), Fudan University, Shanghai, China. He received his degree of Master of Media and Governance from Keio University, Japan in 2016. He can be reached at 11210170034@fudan.edu.cn. 